\title{
KEPRIBADIAN SEORANG PENDIDIK TERHADAP MINAT BELAJAR MATEMATIKA
}

\author{
Siti Aisyah \\ Program Studi Pendidikan Matematika, Tarbiyah, Universitas Islam Sultan Syarif \\ Kasim Riau, Pekanbaru

\section{Email : sitiaisyahcha2@gmail.com}

\begin{abstract}
Abstrak
Pendidik dalam dunia pendidikan merupakan seseorang yang sangat penting dalam dunia pendidikan, menjadi seorang guru memiliki tugas yang tidak ringan dalam mendidik siswa, maka dari itu seorang guru harus mempunyai kepribadian yang baik dalam mengajar maupun bergaul dengan siswa agar bisa menarik perhatian siswa dalam belajar sehingga akan tumbuh minatnya dalam mengikuti proses belajar terutama dalam belajar matematika, karena jika seorang siswa tidak terlebih dahulu menyukai gurunya, pelajaran akan sulit diterima, oleh sebab itu dibutuhkan sosok pendidik atau guru yang memiliki kepribadian yang bisa menarik minat siswa untuk belajar terutama dalam belajar matematika.
\end{abstract}

Kata kunci: Kepribadian, Pendidik, Minat Matematika.

\section{PENDAHULUAN}

Untuk meningkatkan minat belajar matematika siswa diperlukan sosok seorang pendidik yang harus membimbing dan menjadi motivator untuk siswa agar dapat meningkatkan kemauan belajar matematika di mana pembelajaran matematika membutuhkan kemampuan berfikir kritis, sistematis, logis, kreatif sehingga tidak semua siswa yang berminat untuk untuk menyukai matematika, oleh sebab itu dibutuhkan seorang pendidik yang memiliki kepribadian yang disenangi oleh siswa, sehingga akan dapat meningkatkan prestasi belajar siswa.

Sebagai seorang pendidik harus memiliki kepribadian yang baik, apalagi di depan siswa supaya dapat menarik perhatian siswa yang dididik, sebagai seorang pendidik juga harus bisa mengangkat citra positif di depan siswa supaya memberikan kesan yang baik terhadap siswa sehingga mereka akan memberikan kesan atau beranggapan seorang yang mendidiknya memiliki kepribadian yang baik atau mereka bisa berangkapan kita memiliki skill yang mantap.

Adapun kepribadian seorang pendidik di sini adalah kepribadian yang ideal seperti kepribadian yang humoris, penyayang, santun, berwibawa, kerendahan hati melayani tanpa pamrih dan lain sebagainya. Ketika kepribadian pendidik sudah bagus atau ideal maka proses belajar akan terasa menyenangkan karena interaksi siswa dan guru sudah terjalin dengan baik. 
Menjadi pendidik tidak hanya dibutuhkan kepintaran dalam menguasai materi secara keseluran namun harus memiliki kepribadian yang disenangi oleh peserta didik, misalkan saja seorang guru yang tidak memiliki sifat atau kepribadian yang baik seperti ketika dalam kelas dia menyuruh muridnya tidak makan di dalam kelas namun dia sebagai guru tidak mencotohkan apa yang disuruhnya, maka ini akan berdampak kepada buruknya citra guru di mata para siswa.

Seorang pendidik harus memberikan kesan yang baik kepada siswa agar proses belajar bisa menyenangkan, pertama pendidik harus menyapa siswa dan mengenal para siswa, tidak hanya mengenal nama, namun harus mengenal mana kesulitan yang dialami oleh siswa dalam mata pelajaran yang diampuh oleh seorang pendidik.

\section{PEMBAHASAN}

\section{Hakikat Kepribadian}

Rochman Noor Hadjam \& Wahyu Widhiarso (2011) mengtakan bahwa Kepribadian merupakan karakter atau sifat perilaku unik dari seseorang, kepribadian ini kinerjanya melalui emosi, pikiran, dan perilaku seseorang yang dapat mempengaruhi orang-orang sekitar. Kepribadian seiring digambarkan dalam hal ciri-ciri yang ditunjukan oleh seseorang tersebut.

Kepribadian adalah sesuatu yang penting untuk semua profesi, begitu juga menjadi seorang pendidik, harus memiliki kepribadian yang baik atau ideal agar bisa menjadikan atau mengubah siswa dalam semua hal, baik dari hal pengetahuan, sikap maupun skill. Kepribadian merupakan faktor utama dalam mengajar, terutama dalam kelas, karena tanpa adanya guru yang memiliki kepribadian yang baik tidak akan tercipta suasana atau iklim kelas yang kondusif.

Irsyad Nur Hamid (2018) mengatakan dengan adanya kepribadian baik yang dimiliki oleh seorang pendidik, seperti kasih sayang, humoris, santun, berwibawah, rendah hati, melayani tanpa pamrih dan lain sebagainya akan berdampak pada terciptanya iklim kelas yang kondusif, sehingga membuat siswa yang dididik akan nyaman dalam mengikuti proses belajar, maka akan timbul minat untuk belajar apalagi dalam belajar matematika.

Kepribadian seorang pendidik memiliki kelebihan tersendiri jika diterapkan dalam kelas karena ia akan memberikan kesenangan terhadap siswa-siswanya. Adapun pendidik yang dapat dikatakan memiliki kepribadian yang baik adalah pendidik yang mampu menarik perhatian dan menundukkan hati peserta didiknya, sehingga hati mereka akan tersentuh untuk belajar dan membuat mereka bisa merasakan sosok pendidik layaknya teman dekat atau sahabat karib.

Dedi Syaputra mengatakan (2016: 4) suksesnya seorang pendidik tergantung dari kepribadiannya, luasnya ilmu tentang materi pelajaran serta banyaknya pengalaman. Tugas seorang guru itu sangat berat dan tidak mampu dilaksanakan kecuali apabila kuat kepribadiannya, mencintai tugas serta ikhlas dalam mengerjakannya. 
Adapun sesuatu yang harus dilakukan oleh seorang pendidik yang berkepribadian baik jika mengajar dalam kelas, yaitu menerapakan 4S (senyum, sapa, salam dan santun), ketika hal ini sudah diterapkan maka akan tercipta suasana kelas yang kondusif dan menarik minat siswa untuk mengikuti proses belajar.

\section{Kompetensi Kepribadian}

Muh. Ahadi (2017) mengatakan kompetensi kepribadian merupakan kemampuan personal yang wajib dimiliki oleh seorang pendidik dengan menunjukkan kepribadian yang berkompeten, mantap, dewasa serta arif dan bijaksana agar bisa dijadikan teladan oleh peserta didik, adapun kempampuan kompetensi kepribadian guru adalah meliputi kepedulian, memahami keluhan peserta didik secara individual serta bisa mengatur bagaimana hubungan antara guru dan murid.

Adapun Kompetensi kepribadian yang diungkapkan oleh Sukanti dalam journal Muh Ahadi meliputi :

1. Menunjukkan diri sebagai pribadi yang mantap, stabil, arif, dan berwibawa

2. Menunjukkan diri sebagai pribadi yang berakhlak mulia serta teladan bagi peseta didik dan masyarakat

3. Menilai hasil kerja sendiri

4. Selalu mengembangkan diri untuk lebih baik kedepannya

Muhammad Anwar (2018) mengatakan banyak faktor yang dapat menyebabkan minat dan hasil belajar siswa diantaranya faktor dari gurunya yaitu kepribadian atau karakter yang ada pada guru ketika mengajar dan sarana seperti alat peraga matematika yang tersedia disekolah. Jika guru bisa menerapkan atau menciptakan pembelajaran matematika dengan kreatif dan menyenangkan dengan memperhatikan kondisi siswa maka akan didapar hasil belajar yang baik serta guru harus pandai dalam memanfaatkan sarana yang ada.

\section{Kriteria Guru yang Berkepribadian Baik} baik :

Berikut disajikan beberapa kriteria yang termasuk guru berkepribadian

a. Memiliki kepribadian mantap dan stabil

Maulana Lucky Hakim (2012) mengatakan kepribadian yang mantap dan stabil ini menekan bahwa guru harus bisa meredam emosi dan menjaga kehormatannya sebagai seorang guru, dalam menghadapi suatu permasalahan seorang guru harus bisa meredam emosi dan menyelesaikan permasalahan tersebut dengan hati yang tenang sehingga dapat menjaga kehormatannya di depan siswa. Jika seorang guru tidak bisa mengendalikan emosi dalam menyelesaikan masalah maka para siswa akan merasa takut dan itu pastinya menyebabkan kurangnya minat untuk mengikuti proses belajar serta akan membuat hilangnya konsentrasi belajar karena siswa akan kwatir akan dimarahi. 
b. Mempunyai kepribadian yang dewasa

A.Shilpy Oktavi (2019) mengatakan Guru sebagai pribadi yang memiliki kepribadian baik dituntut untuk memiliki kepribadian yang dewasa karena dengan adanya kepribadian dewasa yang dimiliki oleh seorang guru maka siswa kan merasakan kenyamanan bersama guru tersebut karena merasa mengayomi mereka dalam belajar, oleh karena itu akan timbulnya rasa nyaman dalam belajar dan pastinya akan timbul untuk lebih berminat dalam mempelari materi.

c. Mempunyai Jiwa humoris

Sapto Dewi Rini (2016) mengatakan dengan adanya jiwa humoris yang dimiliki oleh seorang guru akan membuat siswa tidak bosan dalam belajar karena dengan adanya selingan humor dalam pelajaraan maka siswa akan membuat siswa tertawa dan bisa mengurangi rasa sters dari siswa terebut, karena jika guru yang mengajar terlalu serius akan menimbulkan rasa bosan dalam diri siswa dalam belajar, sehingga akan menurutkan minat siswa untuk mengikuti proses belajar dengan guru seperti ini, lain halnya dengan guru yang pandai menyelingi proses belajar dengan sedikit humor maka siswa akan merasakan enaknya belajar.

d. Menerapakan 4S (Senyum, sapa, salam, dan santun) Guru yang menerapakan 4 hal ini ketika mengajar di kelas, maka proses belajar mengajar akan menyenangkan karena di sini akan terjalin interaksi yang baik antara guru dan siswa.

1. Senyum

Setiap masuk kelas guru harus melihat aura bahagia kepada para siswa dalam kelas dengan memulai dengan senyuman, dengan adanya senyuman ini maka siswa akan merasa bahagia melihat gurunya, karena jika gurunya menunjukkan wajar yang datar atau kerutan kening di depan siswa maka akan timbul ketidaknyamanan dihati siswa untuk belajar.

2. Salam

Sebelum memulai pelajaran seorang guru harus memulai dengan pembukaan atau salam agar terjalin keakraban antara siswa dan guru.

3. Sapa

Menjadi seorang guru seharusnya tidak langsung memulai pelajaran, sebaiknya lakukan pengabsenan siswa dan mengenal nama-nama siswa yang hadir dalam kelas.

4. Santun

Sopan santun ini harus ada pada setiap individu, terutama dalam diri seorang pendidik, karena dengan kesopanan ini maka orang lain akan menghormati sikap seseorang. Jika seorang guru yang mengajar tidak memiliki kesopanan dalam mengajar dalam mengajar di kelas seperti jika duduk di depan kelas tidak sesuai dengan adap sebagai seorang guru atau ada seorang guru yang merokok di depan siswa.

e. Mempunyai kepribadian yang berwibawa 
Guru yang berwiba biasanya akan dihormati oleh peserta didik dan peserta didik juga akan segan kepada guru tersebut, maka jika tidak mengikuti proses belajar atau kurang berminat dalam mengikuti proses belajar dengannya para siswa akan merasa segan.

f. Mempunyai semangat dan antusiasme

Guru yang semangat dan antusias dalam mengajar pasti akan membuat siswa juga semangat dalam belajar dan siswa juga akan megikuti apa yang disuruh oleh gurunya. Guru yang antusiasme dalam belajar memiliki dua kompnonen dasar yaitu minat dan niat yang tulus untuk mengajar sehingga memancarkan energy positif kepada siswa yang didiknya.

\section{SIMPULAN}

Dengan adanya kepribadian baik yang ditampilkan oleh seorang pendidik dihadapan siswa dalam mendidik terutama dalam mengajar matematika dalam kelas, maka siswa akan senang dalam menerima pelajarannya dan tidak lagi memikirkan sulitnya materi karena pendidiknya mempunyai kepribadian yang menyenangkan. Sehingga akan timbul minat dan semangat dalam mengikuti proses belajar.

\section{DAFTAR PUSTAKA}

Ahadi, Muh. 2017. Pengembangan Kompetensi Profesionalisme Guru Untuk Menyiapkan Pembelajaran yang Bermutu. Prosiding Seminar Nasional.

Anwar, Muhammad. 2018. Menjadi Guru Profesional. Jakarta : Prenadamedia Group.

Hadjam, Rochman Noor \& Widhiarso, Wahyu. 2011. Efikasi Mengajar Sebagai Mediator Peranan Faktor Kepribadian Terhadap Performasi Mengajar Guru. Humanitas. 1 (8), 2-3.

Hakim, Maulana Lucky. 2012. The Great Theacher : Membedah Aspek-Aspek Kepribadian Guru Ideal dan Membentuk Perilaku Siswa dalam Novel "Pertemuan Dua Hati" Karya NH. Dini. Jurnal Pendidikan Dompet Dhuafa, 1 (2), 2-3.

Hamid, Nur Irsyad. 2018. Kepribadian Guru Bimbingan Konseling yang Ideal Bagi Siswa SMA Se Kecamatan Gombang. Jurnal Riset Mahasiswa Bimbingan Konseling, 1 (4), 87-90.

Indrawati, Yuliani. 2006. Faktor-Faktor yang Mempengaruhi Kinerja Guru Matematika dalam Pelaksanaan Kurikulum Berbasis Kompetensi (KBK) pada Sekolah Menengah Atas Kota Palembang. Jurnal Manajemen \& Bisnis Sriwijaya.7 (4), 43.

Napitupulu, Dedi Syaputra. 2016. Kompetensi Kepribadian Guru PAI dalam Mengembangkan Ranah Afektif Siswa di MAN 2 Model Medan. Jurnal Pendidikan Agama Islam. 2 (5), hlm.

Oktavia, A. Shilphy. 2019. Sikap dan Kinerja Guru Profesional. Yogyakarta : CV Budi Utama. 
Oktradiksa, Ahwy. 2012. Pengembangan Kualitas Kepribadian Guru. Jurnal Pendidikan Islam, 2 (6), 6-7.

Rini, Sapto Dewi dkk. 2016. Kompetensi Kepribadian Guru BK (Survei pada Guru Bimbingan dan Konseling Sekolah Menengah Pertama dan Sederajat SeKecamatan Citeureup). Jurnal Bimbingan Konseling. 1 (5), 27.

Saragih, Hasan A. 2008. Kompetensi Minimal Seorang Guru dalam Mengajar. Jurnal Tabularasa PPS Unimed, 1(5), 27-28.

Sari, Wulan Suci. 2012. Pengaruh Model Pembelajaran dan Tipe Kepribadian Terhadap Hasil Belajar Fisika pada Siswa SMP Swasta di Kecamatan Medan Area.Jurnal Tabularasa PPS Unimed, 1 (9), 38-39.

Tandikombong, Martius \& Sendana, Aris Kaban. 2019. Analisis Kepribadian Guru Bahasa Inggris Terhadapa Motivasi Siswa SMK. SPP. St. Paulus Makale dalam Pembelajaran Bahasa Inggris. Jurna KIP. 2 (8), 2-3.

Winarso, Widodo. 2015. Perbedaan Tipe KepribadianTerhadap Sikap Belajar Matematika Siswa Kelas X SMA Islam Al-Azhar 5 Cirebon. Jurnal Sainsmat, 1 (4), 67-69 